Full Paper

www.mdpi.org/molecules

\title{
Synthesis and Antibacterial Properties of New 8-Nitrofluoroquinolone Derivatives
}

\section{Yusuf M. Al-Hiari *, Inas Saleh Al-Mazari, Ashok K. Shakya ${ }^{\dagger}$, Rula M. Darwish and \\ Rana Abu-Dahab}

Faculty of Pharmacy, University of Jordan, Amman 11942 Jordan

${ }^{\dagger}$ Present address: Department of Medicinal and Pharmaceutical Chemistry, Faculty of Pharmacy and Medical Sciences, Amman University, Amman-19328, Jordan

* Author of whom correspondence should be addressed; E-mail: al_hiariyusuf@hotmail.com; Fax: (+962) 65339649

Received: 13 May 2007; in revised form: 19 June 2007 / Accepted: 20 June 2007 / Published 30 June 2007

\begin{abstract}
The objective of this research was the preparation of new 8-nitrofluoroquinolone models and investigation of their antibacterial properties. The work initially involved large scale preparation of the synthon 7-chloro-1-cyclopropyl-6-fluoro-8-nitro-4oxo-1,4-dihydroquinoline-3-carboxylic acid (3), followed by introduction of substituted primary amine appendages at the C-7 position to give derivatives 9a-g, in which the amino group is appended to substituted benzenes or aromatic heterocycles, is part of a primary $\alpha$ amino acid or just a simple primary aliphatic amine. This nucleophilic aromatic substitution step was a very simple procedure since the 8-nitro group of the above synthon facilitated the addition of weak nucleophiles at C-7. All compounds prepared were fully identified and characterized using NMR, IR, EA and MS, and were consistent with expected structures. The prepared targets and the intermediates have shown interesting antibacterial activity against gram positive and/or gram negative strains. In particular, the $p$-toluidine, $p$-chloroaniline and aniline derivatives showed good activity against $S$. aureus with MIC range $\approx 2-5 \mu \mathrm{g} / \mathrm{mL}$. In conclusion, more lipophilic groups seem to enhance activity against gram positive strains.
\end{abstract}


Keywords: 8-Nitrofluoroquinolone Derivatives; Fluoroquinolone; Antibacterial Properties.

\section{Introduction}

In recent years, the numbers of life threatening infections caused worldwide by multi-drug resistant Gram-positive and Gram negative pathogenic bacteria have reached an alarming level. The quinolone antibacterials constitute a major addition with a broad spectrum of in-vitro and in-vivo chemotherapeutic efficiency. A number of quinolines like ciprofloxacin (1), norfloxacin (2), levofloxacin and moxifloxacin are being marketed and many are nowadays in clinical trials [1].

In our search for potent fluoroquinolone derivatives, it has been found that although some were based on modifications on other positions, the most successful compounds developed were based on modifications at C-7, and it has been found that the spectrum and level of antibacterial activity is highly affected by the nature of the C-7 substituent group. In addition to the inhibition of DNA gyrase and cell permeability, the C-7 substituents have been proposed as the domain that interacts with the enzyme to further strengthen drug binding [2,3]. In general, C-7 substitution should involve an electron donating group in order to increase electron density on the carbonyl oxygen at C-4 position of the standard structure of 4-quinolone-3-carboxylic acid (Figure 1) [2, 3].

Figure 1. General route for introducing substituted primary amine groups.<smiles>[R]c1cc2c(cc1F)c(=O)c(C(=O)O)cn2[R1]</smiles>

ciprofloxacine (1) $\quad\left(\mathrm{R}_{1}=c-\mathrm{C}_{3} \mathrm{H}_{5} ; \quad \mathrm{R}_{2}=N\right.$-piperazinyl $)$

norfloxacin (2) $\quad\left(\mathrm{R}_{1}=\mathrm{C}_{2} \mathrm{H}_{5} ; \quad \mathrm{R}_{2}=N\right.$-piperazinyl $)$

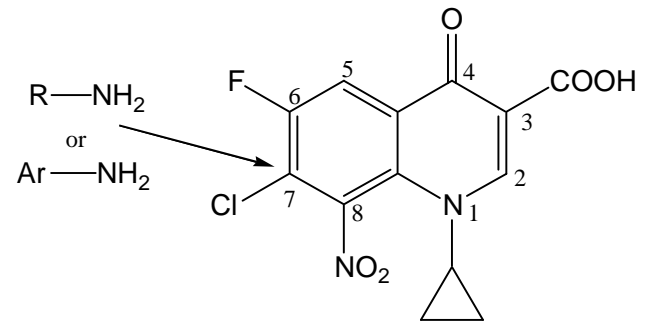

Synthon 3

Arylalkyl or haloalkyl substitution on the nitrogen at C-7 gives compounds with acceptable activity. Medium sized $N$-heterocyclic rings (5- and 6-membered) located at C-7 of the quinolone have contributed most significantly to their antibacterial activity. Linear substituents with one or two heteroatoms (usually $\mathrm{N}$ ) were investigated and gave compounds that were not very effective. Groups larger than piperazine led to less active compounds [4, 5, 6]. Methyl-, chloro- and acyclic aminogroups at $\mathrm{C}-7$ (e.g. $-\mathrm{NHNH}_{2},-\mathrm{NHR},-\mathrm{NHCH}_{2} \mathrm{CH}_{2} \mathrm{NH}_{2}$ ) resulted in moderate to weak biological activity, compared to ciprofloxacin [5, 7].

Although substitution on C-7 has been thoroughly investigated, not much information about (substituted aliphatic or aromatic) primary amines has been reported. Most synthesized 7-amino derivatives were appendages consisting of secondary amines, mostly as part of heterocyclic rings. This was thought to be due to the fact that primary amine (aliphatic or aromatic) might not exhibit 
biological activity and were therefore not worthy of investigation. Moreover, the weak nucleophilcity of the amine, especially in case of aromatic systems, toward C-7 and the harsh reaction conditions needed hindered real attempts to produce large scale active derivatives. Our literature survey revealed that compounds with substituted primary amine derivatives are also potent antimicrobial agents [8]. On the basis of above mentioned findings, this work involves the synthesis of novel C-7 substituted derivatives of 1-cyclopropyl-6-fluoro-8-nitro-4-oxo-1,4-dihydroquinoline-3-carboxylic acid (3) having an 8-nitro substituent as an electron withdrawing group and the evaluation of the biological activity of the new derivatives (Figure 1). This synthon contains an electron withdrawing group (the 8-nitro group) ortho- to C-7, which is the target position for new substitutions. This nitro group at C-8 allows the increment of the nucleophilicity at position 7 and facilitates amino substitution at C-7 by nucleophilic aromatic substitution (addition-elimination) reactions.

\section{Results and Discussion}

Synthesis of 7-chloro-1-cyclopropyl-6-fluoro-8-nitro-4-oxo-1,4-dihydro-quinoline-3-carboxylic acid (3)

Our initial exploration of routes for the preparation of synthon 3 started with nitration of the fluoroquinolone nucleus using fuming $\mathrm{HNO}_{3}$. These attempts failed to introduce a nitro group at C-8. as the final product obtained was the result of decarboxylation followed by nitration at C-3. The starting material 3 was then synthesized by reported methods [7,9] with major modification (Scheme 1). 2,4-Dichloro-5-fluoro-3-nitrobenzoic acid (4) was heated with thionyl chloride in benzene to produce acid chloride 5, which upon treatment with ethyl 3-( $N, N$-dimethylamino)acrylate gave ethyl-3( $N, N$-dimethylamino)-2-(2,4-dichloro-5-fluoro-3-nitrobenzoyl)acrylate (6). Compound 6 reacted with cyclopropylamine to produce ethyl 3-( $N$-cyclopropylamino)-2-(2,4-dichloro-5-fluoro-3-nitrobenzoyl) acrylate (7), which upon heating with $\mathrm{DMF}$ and $\mathrm{K}_{2} \mathrm{CO}_{3}$ was converted into ethyl 7-chloro-1cyclopropyl-6-fluoro-8-nitro-4-oxo-1,4-dihydroquinoline-3-carboxylate (8).

Finally, methanolic HCl hydrolysis gave the target 7-chloro-1-cyclopropyl-6-fluoro-8-nitro-4-oxo1,4-dihydroquinoline-3-carboxylic acid (3) in good yield (Scheme 1). This sequence was amenable to scale-up and fifty grams of synthon $\mathbf{3}$ were thus prepared and collected. The new modifications involved distillation of the reaction mixture upon preparation of compound $\mathbf{6}$. This step was carried out to remove excess thionyl chloride at an early stage. Purification of the intermediate 6 also did not require tedious purification of the final product using column chromatography, as carried out in previous reported procedures. The yield figures were significantly improved to about 91-95 \%, while reported yields did not exceed $73 \%$.

This procedure involved dissolving compound 6 in methanol only (to prepare 7) without the need to use a mixture of expensive solvents (ethoxyethane). It was assumed that the previously reported solvent mixtures were used because compound $\mathbf{6}$ was not pure and a mixture of solvents was needed to dissolve all compounds in the sample. The new procedure developed produced a pure solid 7 which was collected as a white crude solid by filtering off the final precipitate. Washing with small amounts of ethanol was enough to produce the pure product 7 with significantly high yield (93\%). 
Scheme 1. Preparation of cipro ester 8 and cipro acid 3.<smiles>CC#CC(=O)C(=CNC)C(=O)c1cc(F)c(Cl)c([N+](=O)[O-])c1Cl</smiles><smiles>CCOC(=O)c1cn(C2CC2)c2c([N+](=O)[O-])c(Cl)c(F)cc2c1=O</smiles>

Reagents and conditions: (i) $\mathrm{SOCl}_{2}$, dry benzene, reflux; (ii) $\mathrm{EtOCOCH}=\mathrm{CHNMe}_{2}, \mathrm{Et}_{3} \mathrm{~N}$, dry benzene (iii) cyclopropylamine, $\mathrm{MeOH}$; (iv) DMF, $\mathrm{K}_{2} \mathrm{CO}_{3}$; (v) $\mathrm{HCl} / \mathrm{EtOH}$

Preparation of ester $\mathbf{8}$ was reported to be a difficult step that needs column chromatography purification, yielding not more than $65 \%$ in the best experiments. This work requires no chromatographic separation. The cyclization involved heating for a short time $(2 \mathrm{~h})$ but at lower temperature $\left(85^{\circ} \mathrm{C}\right.$ instead of $160^{\circ} \mathrm{C}$ ). The reaction was terminated by pouring the reaction mixture onto crushed ice, and precipitate was collected and dried. The purification step in this work was carried out by simple cyclization step to produce the pure ester $\mathbf{8}$ in more than $89 \%$ yield. The final hydrolysis step was carried out in acidic media to get pure acid 3 in $92 \%$ yield. In conclusion, the proposed procedure gave significantly higher overall yields (above $95 \%$ ). It also uses cheaper and safer solvents, involves much simpler techniques and fewer steps, which ultimately save money and efforts. In addition, costly chromatographic techniques are avoided to further reduce the cost.

Introduction of primary amine appendages at C-7

Preparation of the novel quinolone compounds 9a-g was carried out employing a regiospecific nucleophilic aromatic substitution of the 7-chloro-1-cyclopropyl-6-fluoro-8-nitro-4-oxo-1,4-dihydroquinoline-3-carboxylic acid (3) with appropriate substituted primary amines (Scheme 2). This was based on introducing different groups regarding the type of substitution on the primary amine group (screening process), utilizing the new procedure which is facilitated by the existence of the C-8 nitro group on synthon 3.

The previous procedures to introduce nucleophiles at C-7 involved using DMF, DMSO, pyridine and heating at very high temperature [10]. This involves harsh conditions, long times and produced low yields, due to difficulties in separation and purification.

The aqueous procedure involves adding three molar excess of the substituted primary amine to the synthon 3 in aqueous ethanol and 18 molar excess of the base $\left(\mathrm{NaHCO}_{3}\right)$. Stirring of the mixture for 25 days at moderate temperature $\left(60-80{ }^{\circ} \mathrm{C}\right)$ furnished a yellow to orange crude mixture. After a third 
extraction process of the aqueous mixture at $\mathrm{pH} 3-4$, the final product precipitated as bright yellow pure compound and in very high yield (greater than $80 \%$ ) with most derivatives.

Scheme 2. Synthesis of compounds 9a-g from different amines.

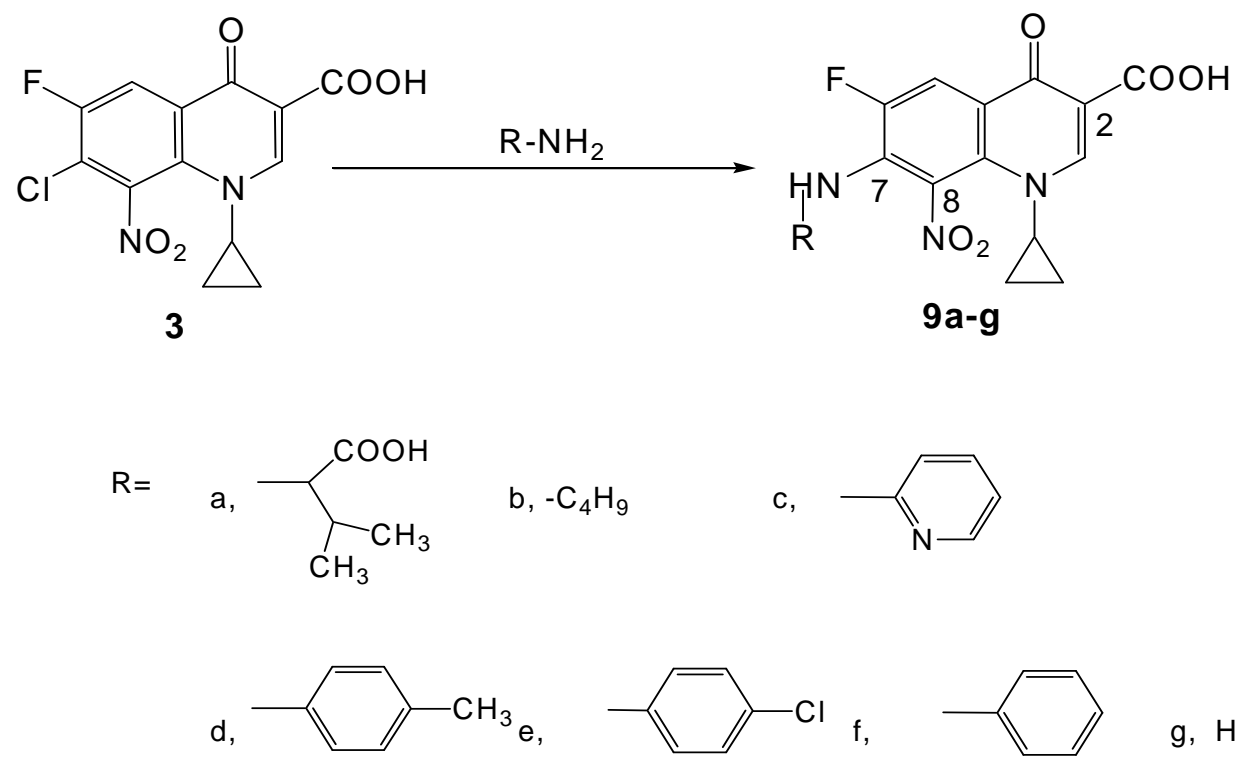

The structures of the prepared fluoroquinolone derivatives 9a-g and intermediates were confirmed based on IR, MS, ${ }^{1} \mathrm{H}$ - and ${ }^{13} \mathrm{C}-\mathrm{NMR}$ spectral data, which were fully consistent with proposed structures. Signal assignments to various proton and carbons were mostly determined following DEPT and 2D COSY, HMQC and HMBC experiments. It was clearly evident that $\mathrm{H}-5$ in all derivatives, which resonate at around $8.0 \mathrm{ppm}\left(\mathrm{d},{ }^{3} J_{\mathrm{H}-\mathrm{F}} \approx 13 \mathrm{~Hz}\right)$ showed a consistent doubling pattern in all compounds due to coupling with fluorine. This phenomenon was also clear in the neighboring carbons, according to their position. Long range correlations are observed between $\mathrm{H}-2$ and each of C-8a, C-4 and 4a. Corresponding long range correlations are also observed between $\mathrm{H}-5$ and its neighbor carbons.

All skeletal carbons of the fused benzene ring are recognizable by both their signal splitting arising from coupling with fluorine atom (different value of $J$ for each carbon) and from long range coupling with surrounding protons. It was evident from the new broad signal at around 7 to 8 ppm for $\mathrm{NH}$ at C-7 that the primary amine constituent was introduced. The cyclopropyl methine proton (H-1') experienced a downfield shift in all derivatives $(3.7 \mathrm{ppm})$ probably due to de-shielding effect of the adjacent nitrogen at position 1 .

Low-resolution mass analysis was carried out for some models, however, the available electron impact (EI) technique failed to detect the exact mass when the compounds analyzed as acids. Only the ester (8) showed the exact mass upon high resolution analysis. Those which showed the molecular ion at low resolution analysis are reported within experimental part.

Synthesis of novel compound having 7-(thaizol-2-yl-)amino-, 7(3-carboxy-pyridine-2-yl)amino-, 7-(3-nitrophenyl)-amino- and 7-(2-carboxy-phenoxy)- functional group did not worked with the current method (Scheme 3). These reactions produce entirely different major and minor side 
compounds (10 and 11) which are mentioned in the experimental part and are identified by spectral techniques. Both products were isolated from different experiments and fully identified.

Scheme 3. Side products obtained with different amines (failed attempts).

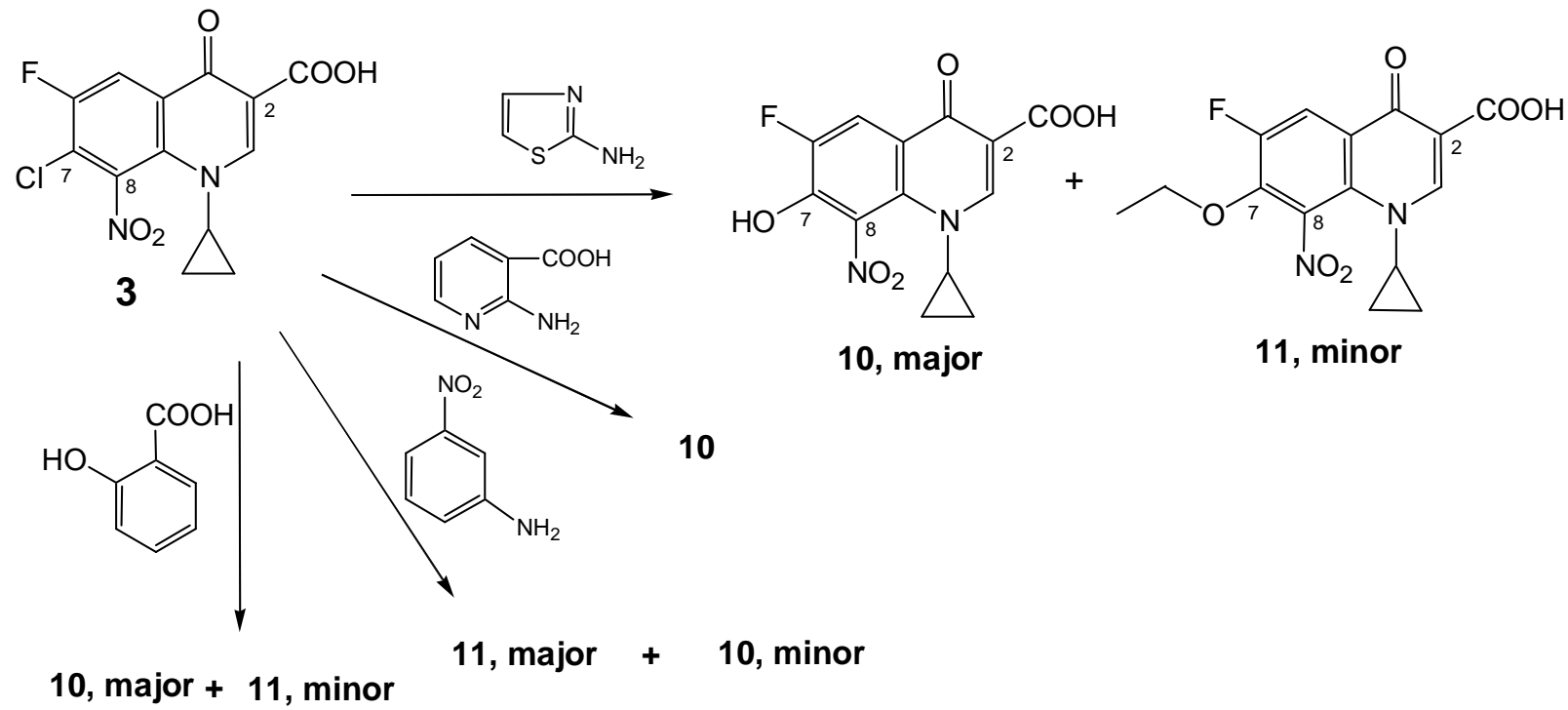

\section{Antibacterial activity}

Evidence in the literature showed that the nature of the functional group at the C-7 position of the quinolone system has a great influence on the spectrum and extent of the antibacterial activity [2, 3]. It has been demonstrated by other workers that the activity against bacteria was related to the lipophilicity of the side chain at C-7 of the compounds as well as the lipophilicity of the substitution at N-1 [11]. It is generally assumed that the more lipophilic quinolones should have best ability to penetrate the lipophilic wall of Gram positive bacteria and thus have better activity against these bacteria. Moreover, it has been reported that reducing the lipophilicity of the fluoroquinolone molecule resulted in urinary recovery of the unchanged compound at a higher ratio [12].

The pure synthesized compounds 9a-g (Scheme 2), side reaction products $\mathbf{1 0}$ and $\mathbf{1 1}$ (Scheme 3), synthon $\mathbf{3}$ and ester $\mathbf{8}$ (Scheme 1) were evaluated for in vitro antibacterial activity against $E$. coli and $S$. aureus. These microorganisms were chosen to represent species of Gram negative and Gram positive bacteria, respectively. The initial investigation by agar diffusion method (Table 1) show that all the tested compounds have some antimicrobial activity against either E. coli and/or S. aureus; except for the ester $\mathbf{8}$ that shows no activity against both types of bacteria. Compound $\mathbf{8}$ is an ester form of the synthon 3; it is expected for any fluoroquinolone ester not to have any in vitro activity but might have same in vivo activity due to its hydrolysis to the acid form [13].

MIC results have indicated that the full structure of the C-7 appendages played an important role in determination of the activity. It was evident that both lipophilicity and solubility have affected the activity of these compounds and consequently antimicrobial results. 
Table 1. Zones of inhibition of some synthesized compounds (at saturated concentration) against E. coli and S. aureus.

\begin{tabular}{|c|c|c|c|}
\hline \multirow{2}{*}{$\begin{array}{c}\text { New } \\
\text { Compound } \\
\text { Number }\end{array}$} & \multirow{2}{*}{$\begin{array}{c}\text { Saturated } \\
\text { concentration } \\
\text { mg/mL }\end{array}$} & $\begin{array}{c}|c| \\
\text { Inhibition zone }(\mathrm{mm})\end{array}$ \\
\cline { 3 - 4 } & 16 & 8739 & 6538 \\
\hline $\mathbf{3}$ & 26 & 7 & 33 \\
$\mathbf{8}$ & 96.2 & 34 & 7 \\
$\mathbf{9 a}$ & 18.6 & 12 & 35 \\
$\mathbf{9 c}$ & 2.4 & 7 & 7 \\
$\mathbf{9 d}$ & 7 & 30 & 17 \\
$\mathbf{9 g}$ & 6.8 & 23 & 33 \\
$\mathbf{1 0}$ & 9.4 & 28 & 29 \\
$\mathbf{1 1}$ & - & 7 & 35 \\
DMSO & 2.6 & 46 & 7 \\
Ciprofloxacin & & & 42 \\
\hline
\end{tabular}

Note: diameter of wells $=7 \mathrm{~mm}$

Compounds $\mathbf{3}$ and $\mathbf{9 g}$ showed the good antibacterial activity against both, Gram positive and Gram negative bacteria. Both compounds showed higher activity against $S$. aureus with $M I C \approx 0.97$ and 1.2 $\mu \mathrm{g} / \mathrm{ml}$, respectively (Table 2), compared to their activity against $E$. coli with $M I C \approx 4.7$ and $8.8 \mu \mathrm{g} / \mathrm{mL}$, respectively.

Table 2. MIC for the prepared 8-nitrofluoroquinolones against E. coli and S. aureus.

\begin{tabular}{|c|c|c|}
\hline Compound No. & E. coli ATCC 8739 & S. aureus ATCC 6538 \\
\hline $\mathbf{3}$ & 4.7 & 0.97 \\
$\mathbf{9 a}$ & 37.5 & above100 \\
$\mathbf{9 b}$ & 15 & 0.65 \\
$\mathbf{9 c}$ & above 100 & ND* \\
$\mathbf{9 d}$ & ND & 3.5 \\
$\mathbf{9 e}$ & 10 & 4 \\
$\mathbf{9 f}$ & 10 & 5 \\
$\mathbf{9 g}$ & 8.8 & 1.20 \\
$\mathbf{1 0}$ & 75 & 37.5 \\
$\mathbf{1 1}$ & 37.5 & 0.58 \\
Ciprofloxacin & 0.00915 & 0.22 \\
\hline
\end{tabular}

* Note: ND means antibacterial activity was not detected. 
Reduction of activity upon introduction of the amino group is possibly due to the electronwithdrawing chloro group on the nucleus at C-7. Such an observation was also reported upon comparing different 6-fluoro-7-substitutions on the 1-ethyl-1,4-dihydro-4-oxo-6-flouroquinoline-3carboxylic acid nucleus [5].

Among the tested compounds, compounds $\mathbf{1 1}$ and $\mathbf{9 b}$ showed best antibacterial activity against Gram positive bacteria with $M I C \approx 0.58 \mu \mathrm{g} / \mathrm{mL}$ and $0.65 \mu \mathrm{g} / \mathrm{mL}$ respectively (Table 2). It is clearly shown that substitution of the 7-chloro group of 7-chloro-1-cyclopropyl-6-fluoro-8-nitro-4-oxo-1,4dihydroquinoline-3-carboxylic acid (3) by 7-ethoxy (11) or 7-n-butyl (9b) groups resulted in an interesting activity against Gram positive bacteria, which is much stronger than that seen against Gram negative bacteria with $M I C \approx 37.5$ and $15 \mu \mathrm{g} / \mathrm{mL}$, respectively (Table 2). This behavior can be correlated to the lipophilic groups that shifted activity towards Gram positive bacterial in both compounds.

In the same vein, the highly lipophilic groups as in $p$-toluidine derivative $\mathbf{9 d}$, $p$-chloro derivative $\mathbf{9 e}$ and aniline 9f showed a strong activity against Gram positive bacteria with $M I C \approx 3.5 \mu \mathrm{g} / \mathrm{mL}, 4.0$ $\mu \mathrm{g} / \mathrm{mL}$ and $5 \mu \mathrm{g} / \mathrm{mL}$, respectively (Table 2). It is evident by those results that addition of more lipophilic groups to the quinolones standard structure has shifted activity against gram positive bacteria since the ability to penetrate the lipophilic wall of Gram positive bacteria has increased. This finding does have precedent in the literature with other fluoroquinolones [12].

Moreover, such results would eliminate the outer layers of Gram negative bacteria as site of action. It is thus concluded that their mechanism of action is similar to other known fluoroquinolones which were reported to have their activity on DNA enzymes. Again, this is supported by previous literature reports of other fluoroquinolones $[4,14]$.

\section{Cytotoxicity on cancerous epithelial cells}

Preliminary cytotoxicity studies were carried out for the 7 candidate compounds with MCF-7 cells, a human breast adenocarcinoma cell line, to test whether these compounds are toxic to epithelial cells or they would have a potential as anticancer agents. All compounds did not change the proliferation rate of the cells as compared to controls (cells incubated with media only). This would suggest that these derivatives are not toxic to epithelial cells. Further evaluation should be carried out for exact determination of the $\mathrm{IC}_{50}$.

\section{Conclusions}

In conclusion, this work has successfully introduced new substituted primary amine appendages at 8-nitro-fluoroquinolone nucleus utilizing new procedure developed within the course of this work. The fluoroquinolone derivatives were fully identified and characterized using NMR, IR, EA and MS. The antimicrobial properties of all pure compounds were evaluated against E. coli and S. aureus bacteria. Although the selected structures did not follow a specific pattern (structure), they were chosen to have different hydrophilic/lipophilic properties as lead models for further antibacterial investigation.

The results indicate clearly that all new compounds, in addition to the side products, have interesting antimicrobial activity ranging from weak to strong against both strains of bacteria. For the 
targeted compounds, it is concluded that more hydrophilic groups supported antimicrobial activity against Gram negative bacteria; while more lipophilic groups supported antimicrobial activity against Gram positive bacteria as in p-toluidine. This work is consistent with previous findings that an electron-releasing group is still required at C-7, and more lipophilic cyclic structures direct the activity against Gram positive bacteria. Finally, this work has opened the door for new C-7 appendages at 8nitro-fluoroquinolone systems that may produce new clinical antibacterial agents in the future on bulk scale.

\section{Experimental}

\section{General}

Melting points (M.p.) were determined in open capillaries on a Stuart Scientific electrothermal melting point apparatus and were uncorrected. Infrared (IR) spectra were recorded on an Avatar Thermo Nicolet Impact 400 FT-IR spectrophotometer (University of Jordan) using the Smart OmniTransmission software. All samples were prepared as potassium bromide (Acros, Belgium) discs. Nuclear magnetic resonance (NMR) ${ }^{1} \mathrm{H}$ - and ${ }^{13} \mathrm{C}$ - spectra were measured on a Bruker Ultra Shield-300 $\mathrm{MHz}$ instrument (Al-Albeit University, Jordan) operating at $300\left({ }^{1} \mathrm{H}\right)$ and $75 \mathrm{MHz}\left({ }^{13} \mathrm{C}\right)$, respectively. Chemical shifts are given in $\delta(\mathrm{ppm})$ using trimethylsilane $\left(\mathrm{Me}_{3} \mathrm{Si}\right)$ as internal reference; deuterated solvents were used and are stated with each compound. Elemental analysis (EA) of C, H and N were performed on a Euro Elemental analyzer model (EA3000 A), Italy, at Al-Albeit University. The analytical results of the elements were within $\pm 0.4 \%$ of the theoretical values. Thin layer chromatography (TLC) was performed on $10 \times 10 \mathrm{~cm}^{2}$ aluminum plates pre-coated with fluorescent silica gel $\mathrm{GF}_{254}$ (ALBET, Germany) and was visualized using UV lamp (at 254nm wave length/ short wave length/ long wavelength). Mobile phase mixtures were: 94:5:1 chloroform-methanol-formic acid ( $\left.\mathrm{CHCl}_{3}-\mathrm{MeOH}-\mathrm{FA}\right)$ (system 1) and 90:10:1 $\mathrm{CHCl}_{3}-\mathrm{MeOH}-\mathrm{FA}$ (system 2).

\section{Synthesis of synthon 3 (Scheme 1)}

i) Ethyl 3-(N,N-dimethylamino)-2-(2,4-dichloro-5-fluoro-3-nitrobenzoyl) acrylate (6). A mixture of 2,4-dichloro-5-fluoro-3-nitrobenzoic acid (4, $10.2 \mathrm{~g}, 40 \mathrm{mmol})$, and thionyl chloride ( $\left.\mathrm{SOCl}_{2}\right)(19.0 \mathrm{~g}$, $160 \mathrm{mmol})$, dissolved in dry benzene $(120 \mathrm{~mL})$ was refluxed at $75-80{ }^{\circ} \mathrm{C}$ for $3-4 \mathrm{~h}$ under anhydrous conditions. The mixture was then distilled off under reduced pressure to remove solvent and excess thionyl chloride. Dry benzene was then added twice (2 x $20 \mathrm{~mL})$ into the reaction vessel and the mixture was re-distilled so as to remove traces of thionyl chloride. The resulting 2,4-dichloro-5-fluoro3-nitrobenzoyl chloride (5), formed as thick oil, was used as such for the next step without further purification. To a stirred and cooled $\left(5-10{ }^{\circ} \mathrm{C}\right)$ solution of ethyl 3-( $N, N$-dimethylamino)acrylate (6.3 g, $44 \mathrm{mmol}$ ) and triethylamine ( $4 \mathrm{ml}, 8.1 \mathrm{~g}, 80 \mathrm{mmol})$ in dry benzene $(50 \mathrm{ml})$, a solution of the crude acid chloride (prepared above) in dry benzene ( $25 \mathrm{ml}$ ) was added drop by drop. The resulting mixture was stirred continuously for $2 \mathrm{~h}$ at room temperature under anhydrous conditions. Then, the solution was refluxed at $90{ }^{\circ} \mathrm{C}$ for 90 minutes. This crude product was evaporated to dryness, re-dissolved in chloroform; the chloroform was extracted with water $\left(30 \mathrm{~mL}\right.$ ) and dried (with anhydrous $\mathrm{MgSO}_{4}$ ). The 
solvent, chloroform, was then evaporated to dryness under reduced pressure. The residual product (about $20 \mathrm{~mL}$ ) was soaked in methanol $(10 \mathrm{~mL})$ whereby the title compound 6 was produced as yellowish powder that was collected by suction filtration and dried. Yield $\approx 13.8 \mathrm{~g}(91 \%)$. ${ }^{1} \mathrm{H}-\mathrm{NMR}$ $\left(\mathrm{CDCl}_{3}\right): \delta 0.95$ (t, $\left.J=7.1 \mathrm{~Hz}, 3 \mathrm{H}, \mathrm{CH}_{3}\right), 2.97(\mathrm{~s}, 3 \mathrm{H})$ and $3.37(\mathrm{~s}, 3 \mathrm{H})\left[N\left(\mathrm{CH}_{3}\right)_{2}\right], 3.94(\mathrm{q}, J=7.1 \mathrm{~Hz}$, $2 \mathrm{H}, \mathrm{CH}_{2} \mathrm{Me}$ ), 7.27 (d, $\left.{ }^{3} \mathrm{~J}_{\mathrm{H}-\mathrm{F}}=8.2 \mathrm{~Hz}, 1 \mathrm{H}, \mathrm{H}-6\right), 7.91$ (br s, $\left.1 \mathrm{H}, \mathrm{N}-\mathrm{C}\left(3^{\prime \prime}\right)-\mathrm{H}\right) ;{ }^{13} \mathrm{C}-\mathrm{NMR}\left(\mathrm{CDCl}_{3}\right): \delta 13.8$ $\left(\mathrm{CH}_{3} \mathrm{CH}_{2}\right), 43.3,48.4$ [N $\left.\left(\mathrm{CH}_{3}\right)_{2}\right], 60.2\left(\mathrm{CH}_{2} \mathrm{Me}\right), 100.9\left(\mathrm{C}-2^{\prime \prime}\right), 114.5\left(\mathrm{~d},{ }^{2} J_{\mathrm{C}-\mathrm{F}}=23.3 \mathrm{~Hz}, \mathrm{C}-4\right), 116.9$ $\left(\mathrm{d},{ }^{2} J_{\mathrm{C}-\mathrm{F}}=23.1 \mathrm{~Hz}, \mathrm{C}-6\right), 118.2\left(\mathrm{~d},{ }^{3} J_{\mathrm{C}-\mathrm{F}}=4.5 \mathrm{~Hz}, \mathrm{C}-1\right), 144.2\left(\mathrm{~d},{ }^{3} J_{\mathrm{C}-\mathrm{F}}=6 \mathrm{~Hz}, \mathrm{C}-3\right), 148.8\left(\mathrm{br} \mathrm{d},{ }^{4} J_{\mathrm{C}-\mathrm{F}}\right.$ = $1.3 \mathrm{~Hz}, \mathrm{C}-2), 156.6$ (d, $\left.{ }^{1} J_{\mathrm{C}-\mathrm{F}}=254 \mathrm{~Hz}, \mathrm{C}-5\right), 160.5$ ( $\left.N-\mathrm{C}-3^{\prime \prime}\right), 166.5\left(\mathrm{CO}_{2} \mathrm{Et}\right), 185.1(\mathrm{C}=\mathrm{O})$; IR $(\mathrm{KBr})$ : $v$ 3431, 3073, 2987, 2928, 2864, 1689, 1619, 1553, 1455, 1421, 1374, 1344, 1321, 1278, 1205, 1177 , 1129, $1030 \mathrm{~cm}^{-1}$; Anal. Calcd. for $\mathrm{C}_{14} \mathrm{H}_{13} \mathrm{Cl}_{2} \mathrm{FN}_{2} \mathrm{O}_{5}$ (379.17): C, 44.35; H, 3.46; N, 7.39. Found: C, 44.30; H, 3.38; N, 7.62; $\mathrm{mp}=139-141^{\circ} \mathrm{C}$ (decomposition); $R_{f}$ value in system $1=0.89$ and in system $2=0.90$.

ii) Ethyl 3-(N-cyclopropylamino)-2-(2,4-dichloro-5-fluoro-3-nitrobenzoyl) acrylate (7). A stirred solution of ethyl 3-( $N, N$-dimethylamino)-2-(2,4-dichloro-5-fluoro-3-nitrobenzoyl)acrylate (6, $14.4 \mathrm{~g}$, $38 \mathrm{mmol})$ in methanol $(10 \mathrm{~mL})$ was treated drop-wise with cyclopropyl amine (3.2 $\mathrm{g}, 56 \mathrm{mmol})$. Methanol $(50 \mathrm{~mL})$ was then added and the reaction mixture was stirred at R.T. for $1-2 \mathrm{~h}$. The precipitated white solid product was filtered, washed with cold ethanol (95 \%, $10 \mathrm{~mL}$ ) and dried. Yield $\approx 11.0 \mathrm{~g}$; a second crop of 7 (1.7 g) was obtained upon concentration of the mother liquor. All yield $\approx$ $12.7 \mathrm{~g}(93 \%) .{ }^{1} \mathrm{H}-\mathrm{NMR}\left(\mathrm{CDCl}_{3}\right): \delta 0.88\left(\mathrm{~m}, 4 \mathrm{H}, \mathrm{H}_{2}-2^{\prime} / \mathrm{H}_{2}-3^{\prime}\right), 1.01,0.92(\mathrm{Z} / \mathrm{E}, 2 \mathrm{t}, J=7.1 \mathrm{~Hz}, 3 \mathrm{H}$, $\mathrm{CH}_{3}$ ), 3.00 (m, 1H, H-1'), 3.99, 3.73 (Z/E, 2q, J=7.1 Hz, 2H, CH $2 \mathrm{Me}$ ), 7.10, 7.16 (Z/E, 2d, ${ }^{3} J_{\mathrm{H}-\mathrm{F}}=8.1$ Hz, 1H, H-6), 8.26, 8.35 (Z/E, 2d, $\left.J=14 \mathrm{~Hz}, 1 \mathrm{H}, N-\mathrm{C}\left(3^{\prime \prime}\right)-\mathrm{H}\right), 11.01,9.77$ (Z/E, $2 \mathrm{br} \mathrm{d}, J=14 \mathrm{~Hz}, 1 \mathrm{H}$, exchangeable $N$-H); ${ }^{13} \mathrm{C}-\mathrm{NMR}\left(\mathrm{CDCl}_{3}\right)$ : $\delta 6.7$ (C-2'/C-3'), 13.9, $13.3\left(\mathrm{Z} / \mathrm{E}, \mathrm{CH}_{3}\right)$, 31.0, 30.3 (Z/E, C-1'), 60.2, 60.1 (Z/E, $\left.\mathrm{CH}_{2} \mathrm{Me}\right), 100.3$, 99.8 (Z/E, C-2"), 114.1, 114.0 (Z/E, 2d, $\left.{ }^{2} J_{\mathrm{C}-\mathrm{F}}=23.3 \mathrm{~Hz}, \mathrm{C}-4\right), 115.7$, $116.0\left(\mathrm{Z} / \mathrm{E}, 2 \mathrm{~d},{ }^{2} J_{\mathrm{C}-\mathrm{F}}=23.3 \mathrm{~Hz}, \mathrm{C}-6\right), 117.7,117.9\left(\mathrm{Z} / \mathrm{E}, 2 \mathrm{~d},{ }^{3} J_{\mathrm{C}-\mathrm{F}}=4.7 \mathrm{~Hz}, \mathrm{C}-1\right), 143.9,143.7$ (Z/E, 2d, ${ }^{3} J_{\mathrm{C}-\mathrm{F}}=6.2 \mathrm{~Hz}, \mathrm{C}-3$ ), 148.6 (br d, $\left.{ }^{4} J_{\mathrm{C}-\mathrm{F}}=1.4 \mathrm{~Hz}, \mathrm{C}-2\right), 156.7$ (d, $\left.{ }^{1} J_{\mathrm{C}-\mathrm{F}}=254 \mathrm{~Hz}, \mathrm{C}-5\right), 161.9,161.4$ (Z/E, N-C-3"), 165.7, 167.8 (Z/E, CO $2 \mathrm{Et}), 188.4,186.2$ (Z/E, C = O); IR (KBr): v 3431, 3196, 3068, 3032, 2985, 2906, 1679, 1617, 1545, 1426, 1367, 1316, 1253, 1192, 1151, 1112, 1063, $1021 \mathrm{~cm}^{-1}$; Anal. Calcd. for $\mathrm{C}_{15} \mathrm{H}_{13} \mathrm{Cl}_{2} \mathrm{FN}_{2} \mathrm{O}_{5}$ (390.18): C, 46.06; H, 3.35; Cl, 18.13; N, 7.16. Found: C, 46.34; H, 3.26; N, 7.19; $\mathrm{mp}=142-145{ }^{\circ} \mathrm{C}$ (decomposition); $R_{f}$ value in system $1=0.94$ and in system $2=0.925$.

iii) Ethyl 7-chloro-1-cyclopropyl-6-fluoro-8-nitro-4-oxo-1,4-dihydroquinoline-3-carboxylate (8). To the pure ethyl 3-( $N$-cyclopropylamino)-2-(2,4-dichloro-5-fluoro-3-nitrobenzoyl) acrylate (7, $11.7 \mathrm{~g}, 30$ mmol) was added potassium carbonate $(11.7 \mathrm{~g}, 85 \mathrm{mmol})$ in dimethyl-formamide (DMF, $50 \mathrm{~mL})$ and the mixture was heated at $85{ }^{\circ} \mathrm{C}$ under reflux with continuous stirring. The progress of the cyclization reaction was monitored by TLC (eluent was AcOEt: n-hexane, 1:1 v/v) and was completed within 90$120 \mathrm{~min}$. The reaction mixture was then poured slowly onto crushed ice (500 g) under vigorous stirring for 10-15 min. The gum layer formed was treated with little amount of $\mathrm{MeOH}$. The precipitated pale yellow solid product 8 was collected, washed with water and left to dry in dark. Yield $\approx 9.5 \mathrm{~g}$ (89 \%). ${ }^{1} \mathrm{H}-\mathrm{NMR}\left(\mathrm{CDCl}_{3}\right): \delta 1.11\left(\mathrm{~m}, 4 \mathrm{H}, \mathrm{H}_{2}-2^{\prime} / \mathrm{H}_{2}-3^{\prime}\right), 1.33\left(\mathrm{t}, J=7.1 \mathrm{~Hz}, 3 \mathrm{H}, \mathrm{CH}_{3} \mathrm{CH}_{2}\right), 3.57\left(\mathrm{~m}, 1 \mathrm{H}, \mathrm{H}-1^{\prime}\right)$, 4.30 (q, $J=7.1 \mathrm{~Hz}, 2 \mathrm{H}, \mathrm{OCH}_{2} \mathrm{Me}$ ), $8.27\left(\mathrm{~d},{ }^{3} J_{\mathrm{H}-\mathrm{F}}=8.0 \mathrm{~Hz}, 1 \mathrm{H}, \mathrm{H}-5\right), 8.56$ (s, $\left.1 \mathrm{H}, \mathrm{H}-2\right)$; ${ }^{13} \mathrm{C}-\mathrm{NMR}$ $\left(\mathrm{CDCl}_{3}\right): \delta 11.1\left(\mathrm{C}-2^{\prime} / \mathrm{C}-3^{\prime}\right), 14.4\left(\mathrm{CH}_{3} \mathrm{CH}_{2}\right), 37.9\left(\mathrm{C}-1^{\prime}\right), 61.4\left(\mathrm{OCH}_{2} \mathrm{Me}\right), 111.8(\mathrm{C}-3), 115.6\left(\mathrm{~d},{ }^{2} J_{\mathrm{C}-\mathrm{F}}\right.$ 
$=23.0 \mathrm{~Hz}, \mathrm{C}-5), 122.0\left(\mathrm{~d},{ }^{2} J_{\mathrm{C}-\mathrm{F}}=23.7 \mathrm{~Hz}, \mathrm{C}-7\right), 130.1\left(\mathrm{~d},{ }^{3} J_{\mathrm{C}-\mathrm{F}}=5.0 \mathrm{~Hz}, \mathrm{C}-4 \mathrm{a}\right), 130.8\left(\mathrm{~d},{ }^{4} J_{\mathrm{C}-\mathrm{F}}=3.0\right.$ $\mathrm{Hz}, \mathrm{C}-8 \mathrm{a}), 140.8$ (d, $\left.{ }^{3} J_{\mathrm{C}-\mathrm{F}}=1.6 \mathrm{~Hz}, \mathrm{C}-8\right), 151.8$ (C-2), 154.4 (d, $\left.{ }^{1} J_{\mathrm{C}-\mathrm{F}}=258 \mathrm{~Hz}, \mathrm{C}-6\right), 164.0\left(\mathrm{CO}_{2} \mathrm{Et}\right)$, $170.8\left(\mathrm{~d},{ }^{4} J_{\mathrm{C}-\mathrm{F}}=2.0 \mathrm{~Hz}, \mathrm{C}-4\right)$; EI MS m/z (\%): 354(28, M+), 337(10), 309(35), 282(61), 265(42), 252(100), 236(57), 226(72), 196(72), 172(32), 160(17), 132(25), 117(7); HRMS: calcd. For $\mathrm{C}_{15} \mathrm{H}_{12} \mathrm{ClFN}_{2} \mathrm{O}_{5}$ : 354.04184, found 354.04281; IR (KBr): $v$ 3225, 3091, 2983, 2909, 2361, 1729, 1634, 1603, 1545, 1463, 1426, 1387, 1344, 1271, 1238, 1173, 1129, $1046 \mathrm{~cm}^{-1}$; Anal. Calcd. for $\mathrm{C}_{15} \mathrm{H}_{12} \mathrm{ClFN}_{2} \mathrm{O}_{5}$ (354.72): C, 50.79; H, 3.41; N, 7.90. Found: C, 50.96; H, 3.35; N, 7.71; mp = 165-167 ${ }^{\circ} \mathrm{C}$ (decomposition); $R_{f}$ value in system $1=0.90$ and in system $2=0.788$.

iv) 7-Chloro-1-cyclopropyl-6-fluoro-8-nitro-4-oxo-1,4-dihydroquinoline-3-carboxylic acid (3). A vigorously stirred suspension of ethyl 7-chloro-1-cyclopropyl-6-fluoro-8-nitro-4-oxo-1,4-dihydroquinoline-3-carboxylate (8, $5.3 \mathrm{~g}, 15 \mathrm{mmol})$ in $12 \mathrm{~N} \mathrm{HCl}(100 \mathrm{~mL})$ and ethanol $(30 \mathrm{~mL})$ was heated at 80-85 ${ }^{\circ} \mathrm{C}$ under reflux conditions. Progress of the ester hydrolysis was monitored by TLC and was completed within 36-48 h. Thereafter, the reaction mixture was cooled, poured onto crushed ice (250 g) and the resulting heavy faint yellow precipitate was collected, washed with cold water ( $2 \times 20 \mathrm{~mL})$, dried and recrystallized from a mixture of chloroform and methanol. Yield $\approx 4.5 \mathrm{~g}(92 \%)$. ${ }^{1} \mathrm{H}$ - NMR (DMSO-d $\mathrm{d}_{6}$ ): $\delta$ 1.02, $1.16\left(2 \mathrm{~m}, 4 \mathrm{H}, \mathrm{H}_{2}-2^{\prime} / \mathrm{H}_{2}-3^{\prime}\right), 3.71\left(\mathrm{~m}, 1 \mathrm{H}, \mathrm{H}-1^{\prime}\right), 8.45\left(\mathrm{~d},{ }^{3} J_{\mathrm{H}-\mathrm{F}}=8 \mathrm{~Hz}, 1 \mathrm{H}, \mathrm{H}-5\right)$, 8.78 (s, 1H, H-2), 13.70 (s, $\left.1 \mathrm{H}, \mathrm{CO}_{2} \mathrm{H}\right) ;{ }^{13} \mathrm{C}-\mathrm{NMR}$ (DMSO-d $\left.{ }_{6}\right): \delta 11.2\left(\mathrm{C}-2^{\prime} / \mathrm{C}-3^{\prime}\right), 39.5\left(\mathrm{C}-1^{\prime}\right), 109.7$ (C-3), $115.3\left(\mathrm{~d},{ }^{2} J_{\mathrm{C}-\mathrm{F}}=23 \mathrm{~Hz}, \mathrm{C}-5\right), 122.7$ (d, $\left.{ }^{2} J_{\mathrm{C}-\mathrm{F}}=23.6 \mathrm{~Hz}, \mathrm{C}-7\right), 128.3\left(\mathrm{~d},{ }^{3} J_{\mathrm{C}-\mathrm{F}}=6.8 \mathrm{~Hz}, \mathrm{C}-4 \mathrm{a}\right)$, $131.9\left(\mathrm{~d},{ }^{4} J_{\mathrm{C}-\mathrm{F}}=2.3 \mathrm{~Hz}, \mathrm{C}-8 \mathrm{a}\right), 141.1\left(\mathrm{~d},{ }^{3} J_{\mathrm{C}-\mathrm{F}}=1.6 \mathrm{~Hz}, \mathrm{C}-8\right), 153.4(\mathrm{C}-2), 154.5\left(\mathrm{~d},{ }^{1} J_{\mathrm{C}-\mathrm{F}}=250 \mathrm{~Hz}, \mathrm{C}-\right.$ 6), $164.8\left(\mathrm{CO}_{2} \mathrm{H}\right), 175.4\left(\mathrm{~d},{ }^{4} J_{\mathrm{C}-\mathrm{F}}=2.2 \mathrm{~Hz}, \mathrm{C}-4\right)$; IR $(\mathrm{KBr}): v$ 3076, 2642, 1718, 1603, 1575, 1541, 1441, 1357, 1329, 1262, 1230, 1195, 1125, $1051 \mathrm{~cm}^{-1}$; Anal. Calcd. for $\mathrm{C}_{13} \mathrm{H}_{8} \mathrm{ClFN}_{2} \mathrm{O}_{5}$ (326.66): C, 47.80; H, 2.47; N, 8.58. Found: C, 47.39; H, 2.43; N, 8.98; $\mathrm{mp}=243-250{ }^{\circ} \mathrm{C}$ (decomposition) (Lit. [9] M. p. $=261{ }^{\circ} \mathrm{C}$, decomposition); $R_{f}$ value in system $1=0.72$ and in system $2=0.363$.

Synthesis of novel title compounds 9a-g (Scheme 2)

\section{General procedure}

A stirred mixture of the substituted primary amine (9 mmol), 7-chloro-1-cyclopropyl-6-fluoro-8nitro-4-oxo-1,4-dihydroquinoline-3-carboxylic acid (3, $1.0 \mathrm{~g}, 3 \mathrm{mmol})$ and sodium hydrogen carbonate ( $1.5 \mathrm{~g}, 18 \mathrm{mmol})$ in $50 \%$ aqueous ethanol $\left(140 \mathrm{~mL}\right.$ ) was heated at $75-80{ }^{\circ} \mathrm{C}$ for $144-156 \mathrm{~h}$ under reflux conditions. More sodium hydrogen carbonate was added $(0.25 \mathrm{~g}, 3 \mathrm{mmol})$ and the mixture was heated for another 144-156 h under reflux conditions. Work-up of the resulting reaction mixture was carried out as described for $\mathbf{9 a}$ below, producing side products in all attempts.

a)(士)-7-(1-Carboxy-2-methylpropylamino)-1-cyclopropyl-6-fluoro-8-nitro-4-oxo-1,4-dihydroquinoline -3-carboxylic acid (9a)

A solution of $D L$-valine $(1.0 \mathrm{~g}, 9 \mathrm{mmol})$ and sodium hydrogen carbonate $\left(\mathrm{NaHCO}_{3}\right)(1.5 \mathrm{~g}, 18$ $\mathrm{mmol})$ in aqueous ethanol $(140 \mathrm{~mL}, 1: 1 \mathrm{v} / \mathrm{v})$ was added to $(1.0 \mathrm{~g}, 3 \mathrm{mmol})$ of 7 -chloro-1-cyclopropyl6-fluoro-8-nitro-4-oxo-1,4-dihydroquinoline-3-carboxylic acid (3). The resulting stirred mixture was 
heated at $60-65^{\circ} \mathrm{C}$. The mixture slowly developed a light yellow color that changed into bright yellow, then into clear orange solution. The progress of the reaction was monitored by TLC (system (1)), and was completed within 100-120 h. The orange solution was extracted with chloroform $\left(\mathrm{CHCl}_{3}, 2 \times 50\right.$ $\mathrm{mL}$ ). The aqueous layer was cooled, adjusted with $3.5 \mathrm{~N} \mathrm{HCl}$ addition to get a solution of $\mathrm{pH}$ 6-7 and another extraction with $\mathrm{CHCl}_{3}(50 \mathrm{~mL})$ was carried out. Further acidification of the leftover of the aqueous layer was performed with $3.5 \mathrm{~N} \mathrm{HCl}$ to $\mathrm{pH}=1-2$, whereby the title compound was precipitated as yellowish solid which was filtered, washed with cold water (2 x $10 \mathrm{~mL}$ ) and dried. Recrystallization of the formed product was carried out from a mixture of chloroform and ethanol (1:1). Yield $\approx 1.1 \mathrm{~g}(90 \%) .{ }^{1} \mathrm{H}-\mathrm{NMR}\left(\mathrm{DMSO}_{\mathrm{d}}\right): \delta$ 0.89, 0.95 (2d, $\left.J=6.8 \mathrm{~Hz}, 6.0 \mathrm{H},\left(\mathrm{CH}_{3}\right)_{2}-\mathrm{CH}\right), 0.92(\mathrm{~m}$, $4 \mathrm{H}, \mathrm{H}_{2}-2^{\prime} / \mathrm{H}_{2}-3^{\prime}$ ), 2.21 (m, 1H, CHMe $), 3.68$ (m, 1H, H.1'), 4.50 (br d, J = 7.2 Hz, CH-CO ${ }_{2} \mathrm{H}$ ), 7.21 (d, $J=8.0 \mathrm{~Hz}, 1 \mathrm{H}, N-\mathrm{H}$ ), 8.07 (d, $\left.{ }^{3} J_{\mathrm{H}-\mathrm{F}}=13.5 \mathrm{~Hz}, 1 \mathrm{H}, \mathrm{H}-5\right), 8.77$ (s, $\left.1 \mathrm{H}, \mathrm{H}-2\right), 13.39$ (br s, $1 \mathrm{H}, \mathrm{CH}-$ $\mathrm{CO}_{2} \mathrm{H}$ ), 14.55 (br s, $\left.1 \mathrm{H}, \mathrm{C}_{3}-\mathrm{CO}_{2} \mathrm{H}\right) ;{ }^{13} \mathrm{C}-\mathrm{NMR}\left(\mathrm{DMSO}_{6} \mathrm{~d}_{6}\right): \delta 10.1\left(\mathrm{C}-2^{\prime} / \mathrm{C}-3^{\prime}\right), 18.0,18.5\left(\left(\mathrm{CH}_{3}\right)_{2}\right)$, $31.6\left(\mathrm{CHMe}_{2}\right), 40.9\left(\mathrm{C}-1^{\prime}\right), 63.2\left(\mathrm{~d}, J_{\mathrm{C}-\mathrm{F}}=11.3 \mathrm{~Hz}, \mathrm{CH}-\mathrm{NH}\right), 109.8(\mathrm{C}-3), 115.2$ (d, ${ }^{2} J_{\mathrm{C}-\mathrm{F}}=22.7 \mathrm{~Hz}, \mathrm{C}-$ 5), $117.8\left(\mathrm{~d},{ }^{3} J_{\mathrm{C}-\mathrm{F}}=7.1 \mathrm{~Hz}, \mathrm{C}-4 \mathrm{a}\right), 129.3\left(\mathrm{~d},{ }^{3} J_{\mathrm{C}-\mathrm{F}}=5.4 \mathrm{~Hz}, \mathrm{C}-8\right), 135.8$ (C-8a), 138.1 (d, ${ }^{2} J_{\mathrm{C}-\mathrm{F}}=14.9$ $\mathrm{Hz}, \mathrm{C}-7), 150.4$ (d, $\left.{ }^{1} J_{\mathrm{C}-\mathrm{F}}=248 \mathrm{~Hz}, \mathrm{C}-6\right), 152.3(\mathrm{C}-2), 165.3\left(\mathrm{C}_{3}-\mathrm{CO}_{2} \mathrm{H}\right), 172.7\left(\mathrm{CH}-\mathrm{CO}_{2} \mathrm{H}\right), 175.6(\mathrm{~d}$, $\left.{ }^{4} J_{\mathrm{C}-\mathrm{F}}=2.5 \mathrm{~Hz}, \mathrm{C}-4\right)$; IR (KBr): $v$ 3308, 3070, 2971, 1733, 1700, 1629, 1549, 1518, 1469, 1321, 1257, 1216, 1144, $1033 \mathrm{~cm}^{-1}$; Anal. Calcd. for $\mathrm{C}_{18} \mathrm{H}_{18} \mathrm{FN}_{3} \mathrm{O}_{7}$ (407.35): C, 53.07; H, 4.45; N, 10.32. Found: C, 52.83; H, 4.69; N, 10.68; $\mathrm{mp}=217-222^{\circ} \mathrm{C}$ (decomposition); $R_{f}$ value in system $1=0.44$ and in system $2=0.175$.

b) 1-Cyclopropyl-6-fluoro-8-nitro-4-oxo-7-(butyl-amino)-1,4-dihydro-quinoline-3-carboxylic acid (9b).

A stirred mixture of $n$-butyl amine (0.66 g, $0.90 \mathrm{~mL}, 9 \mathrm{mmol})$, 7-chloro-1-cyclopropyl-6-fluoro-8nitro-4-oxo-1,4-dihydroquinoline-3-carboxylic acid (3,1.0 g, $3 \mathrm{mmol}$ ) and sodium hydrogen carbonate ( $1.5 \mathrm{~g}, 18 \mathrm{mmol})$ in $50 \%$ aqueous ethanol $(140 \mathrm{~mL})$ was heated at $40-45{ }^{\circ} \mathrm{C}$ for $136 \mathrm{~h}$ under reflux conditions. Work-up of the resulting reaction mixture carried out by extracting the orange solution formed with chloroform $\left(\mathrm{CHCl}_{3}\right)(2 \mathrm{x} 80 \mathrm{~mL})$. The aqueous layer $\mathrm{pH}$ was adjusted with $3.5 \mathrm{~N} \mathrm{HCl}$ addition to get a solution of $\mathrm{pH} \mathrm{6-7}$ and another extraction with $\mathrm{CHCl}_{3}$ was performed. These two chloroform extracts were collected, dried and the product collected was re-crystallized from ethanol and acetone (1:1) in addition to the early two chloroform extracts (at $\mathrm{pH}$ 8-9) producing the title compound 9b as orange crystals. Yield $\approx 0.93 \mathrm{~g}(85 \%) .{ }^{1} \mathrm{H}-\mathrm{NMR}\left(\mathrm{CDCl}_{3}\right): \delta 0.88,0.94\left(2 \mathrm{~m}, 4 \mathrm{H}, \mathrm{H}_{2^{-}}\right.$ $\left.2^{\prime} / \mathrm{H}_{2}-3^{\prime}\right), 1.12-1.19$ (t, $\left.J=6.6 \mathrm{~Hz}, 3 \mathrm{H}, \mathrm{CH}_{3}-\right)$, 1.39-1.53 (m, 2H, $\mathrm{CH}_{3}-\mathrm{CH}_{2}-$ ), 1.65-1.83 (m, 2H, $-\mathrm{CH}_{2}-$ $\mathrm{CH}_{2} \mathrm{CH}_{2-}$ ), $3.0\left(\mathrm{~m}, 2 \mathrm{H},-\mathrm{CH}_{2}-\mathrm{NH}\right), 3.68\left(\mathrm{~m}, 1 \mathrm{H}, \mathrm{H}-1^{\prime}\right), 7.02$ (br s, $\left.1 \mathrm{H}, \mathrm{NH}\right), 8.10$ (d, ${ }^{3} J_{H-F}=13.5 \mathrm{~Hz}$, 1H, H-5), 8.84 (s, 1H, H-2), 14.55 (s, 1H, $\mathrm{CO}_{2} \mathrm{H}$ ); IR (KBr): v 3389, 3081, 2960, 2929, 2866, 2638, 2517, 2369, 1627, 1593, 1502, 1462, 1373, 1351, 1318, 1271, 1236, 1189, 1113, $1032 \mathrm{~cm}^{-1}$; Anal. Calcd. for $\mathrm{C}_{17} \mathrm{H}_{18} \mathrm{FN}_{3} \mathrm{O}_{5}$ (363.34): C, 56.20; H, 4.99; N, 11.56. Found: C, 56.32; H, 5.51; N, 11.65; mp $=185-190{ }^{\circ} \mathrm{C}$ (decomposition); $R_{f}$ value in system $1=0.84$ and in system $2=0.90$. 
c) 1-Cyclopropyl-6-fluoro-8-nitro-4-oxo-7-(pyridin-2-yl amino)-1,4-dihydro-quinoline-3-carboxylic acid (9c).

A stirred mixture of 2-aminopyridine (3.46 g, $9 \mathrm{mmol}$ ), 7-chloro-1-cyclopropyl-6-fluoro-8-nitro-4oxo-1,4-dihydroquinoline-3-carboxylic acid (3,1.0 g, $3 \mathrm{mmol})$ and sodium hydrogen carbonate (1.5 g, $18 \mathrm{mmol})$ in $50 \%$ aqueous ethanol $(140 \mathrm{~mL})$ was heated at $75-80{ }^{\circ} \mathrm{C}$ for $156-162 \mathrm{~h}$ under reflux conditions. Work-up of the resulting reaction mixture was carried out as described for 9a above, producing 9c as yellow solid. Yield $\approx 0.65 \mathrm{~g}(57 \%) .{ }^{1} \mathrm{H}-\mathrm{NMR}\left(\mathrm{DMSO}-\mathrm{d}_{6}\right): \delta 0.89,0.91\left(2 \mathrm{~m}, 4 \mathrm{H}, \mathrm{H}_{2^{-}}\right.$ 2'/ $\mathrm{H}_{2}-3^{\prime}$ ), 3.58 (m, 1H, H.1'), 6.81 (dd, $J=6.61 \mathrm{~Hz}, 6.56 \mathrm{~Hz}, 1 \mathrm{H}, \mathrm{H}-5^{\prime \prime}$ ), 6.91 (d, $J=7.8 \mathrm{~Hz}, 1 \mathrm{H}, \mathrm{H}-3^{\prime \prime}$ ), $7.56\left(\mathrm{~d},{ }^{3} J_{\mathrm{H}-\mathrm{F}}=11.73 \mathrm{~Hz}, 1 \mathrm{H}, \mathrm{H}-5\right), 7.83-7.89$ (m, 3H, superimposed $\mathrm{H}-3^{\prime \prime}$ and $\mathrm{H}-6^{\prime \prime}$ and $\mathrm{N}-\mathrm{H}$ ), 8.45 (s, $1 \mathrm{H}, \mathrm{H}-2$ ), 16.06 (br s, $1 \mathrm{H}, \mathrm{C}(3)-\mathrm{CO}_{2} H$ ); ${ }^{13} \mathrm{C}-\mathrm{NMR}$ (DMSO-d $\left.\mathrm{d}_{6}\right): \delta 10.4\left(\mathrm{C}-2^{\prime} / \mathrm{C}-3^{\prime}\right), 40.7\left(\mathrm{C}-1^{\prime}\right), 106.9$ $\left(\mathrm{d},{ }^{3} J_{\mathrm{C}-\mathrm{F}}=7.0 \mathrm{~Hz}, \mathrm{C}-4 \mathrm{a}\right), 107.5$ (C-3), 108.7 (d, $\left.{ }^{2} J_{\mathrm{C}-\mathrm{F}}=20.6 \mathrm{~Hz}, \mathrm{C}-5\right), 112.6\left(\mathrm{C}-3^{\prime \prime}\right), 113.7\left(\mathrm{C}-5^{\prime \prime}\right)$, $133.0\left(\mathrm{~d},{ }^{3} J_{\mathrm{C}-\mathrm{F}}=7.4 \mathrm{~Hz}, \mathrm{C}-8\right), 136.4$ (C-8a), 136.9 (C-4"), 144.3 (C-6"), 148.6 (C-2), 154.6 (NH-C$\left.2^{\prime \prime}\right), 155.6\left(\mathrm{~d},{ }^{1} J_{\mathrm{C}-\mathrm{F}}=247 \mathrm{~Hz}, \mathrm{C}-6\right), 160.4\left(\mathrm{~d},{ }^{2} J_{\mathrm{C}-\mathrm{F}}=20.4 \mathrm{~Hz}, \mathrm{C}-7\right), 166.7\left(\mathrm{C}(3)-\mathrm{CO}_{2} \mathrm{H}\right), 174.7\left(\mathrm{~d},{ }^{4} J_{\mathrm{C}-\mathrm{F}}\right.$ = $3.6 \mathrm{~Hz}, \mathrm{C}-4)$; IR (KBr): $v$ 3372, 3194, 2691, 1706, 1669, 1627, 1541, 1445, 1404, 1316, 1227, 1111, $1054 \mathrm{~cm}^{-1}$; Anal. Calcd. for $\mathrm{C}_{18} \mathrm{H}_{13} \mathrm{FN}_{4} \mathrm{O}_{5}$ (384.32): C, 56.25; H, 3.41; N, 14.58. Found: C, 56.07; H, $3.29 ; \mathrm{N}, 14.95 ; \mathrm{mp}=234-237^{\circ} \mathrm{C}$ (decomposition); $R_{f}$ value in system $1=0.075$ and in system $2=$ 0.013 .

d) 1-Cyclopropyl-6-fluoro-8-nitro-4-oxo-7-p-tolylamino-1,4-dihydro-quinoline-3-carboxylic acid (9d)

A stirred mixture of $p$-toluidine (0.97 g, $9 \mathrm{mmol})$, 7-chloro-1-cyclopropyl-6-fluoro-8-nitro-4-oxo1,4-dihydroquinoline-3-carboxylic acid (3, $1.0 \mathrm{~g}, 3 \mathrm{mmol})$ and sodium hydrogen carbonate $(0.75 \mathrm{~g}, 9$ $\mathrm{mmol})$ in $50 \%$ aqueous ethanol $(140 \mathrm{~mL})$ was heated at $70-75{ }^{\circ} \mathrm{C}$ for about $120 \mathrm{~h}$. Then extra $p$ toluidine $(0.97 \mathrm{~g}, 9 \mathrm{mmol})$ and sodium hydrogen carbonate $(0.25 \mathrm{~g}, 3 \mathrm{mmol})$ were added and the mixture was heated for $65 \mathrm{~h}$ under reflux conditions. The resulting reaction mixture was a suspension; suction filtration was carried out to get the precipitate, which was not pure. Re-crystallization of the crude product from chloroform $(20 \mathrm{~mL}$ ) was carried out to yield the pure $9 \mathrm{~d}$ as orange solid. Yield $\approx$ 1.13 g (92 \%). ${ }^{1} \mathrm{H}-\mathrm{NMR}$ (DMSO-d $\mathrm{d}_{6}$ ): $\delta 0.99$ (m, 4H, $\left.\mathrm{H}_{2}-2^{\prime} / \mathrm{H}_{2}-3^{\prime}\right), 2.22$ (s, 3H, $\mathrm{CH}_{3}$ ), 3.70 (m, 1H, H. 1'), 6.93 (d, $\left.J=8.0 \mathrm{~Hz}, 2 \mathrm{H}, \mathrm{H}-2^{\prime \prime} / \mathrm{H}-6^{\prime \prime}\right), 7.05$ (d, $\left.J=8.2 \mathrm{~Hz}, 2 \mathrm{H}, \mathrm{H}-3^{\prime \prime} / \mathrm{H}-5^{\prime \prime}\right), 8.13\left(\mathrm{~d},{ }^{3} J_{\mathrm{H}-\mathrm{F}}=11.91 \mathrm{~Hz}\right.$, 1H, H-5), 8.80 (s, 1H, H-2), 8.95 (br s, $1 \mathrm{H}, \mathrm{NH}-\mathrm{Ar}$ ), 14.48 (br s, $1 \mathrm{H}, \mathrm{COOH}$ ); ${ }^{13} \mathrm{C}-\mathrm{NMR}$ (DMSO-d ${ }_{6}$ ): $\delta$ 10.54 (C-2'/C-3'), $20.9\left(\mathrm{CH}_{3}\right), 40.4\left(\mathrm{C}-1^{\prime}\right), 109.4$ (C-3), 114.7 (d, $\left.{ }^{2} J_{\mathrm{C}-\mathrm{F}}=21.83 \mathrm{~Hz}, \mathrm{C}-5\right), 119.2\left(\mathrm{C}-4^{\prime \prime}\right)$, $120.0\left(\mathrm{C}-2^{\prime \prime}, \mathrm{C}-6^{\prime \prime}\right), 120.6$ (d, $\left.{ }^{3} J_{\mathrm{C}-\mathrm{F}}=7.8 \mathrm{~Hz}, \mathrm{C}-4 \mathrm{a}\right), 129.7\left(\mathrm{C}-3^{\prime \prime}, \mathrm{C}-5^{\prime \prime}\right), 133.0(\mathrm{C}-8 \mathrm{a}), 133.5\left(\mathrm{~d},{ }^{2} J_{\mathrm{C}-\mathrm{F}}=\right.$ $15.4 \mathrm{~Hz}, \mathrm{C}-7), 134.3$ (C-8), 139.4 (C-1"), 152.5 (C-2), 152.8 (d, $\left.{ }^{1} J_{\mathrm{C}-\mathrm{F}}=253 \mathrm{~Hz}, \mathrm{C}-6\right), 165.4$ (C(3)$\left.\mathrm{CO}_{2} \mathrm{H}\right), 175.8$ (C-4); IR (KBr): v 3449, 3360, 3063, 2921, 1730, 1620, 1531, 1450, 1362, 1318, 1223, 1102, 1048, $1020 \mathrm{~cm}^{-1}$; Anal. Calcd. for $\mathrm{C}_{20} \mathrm{H}_{16} \mathrm{FN}_{3} \mathrm{O}_{5}$ (397.36): C, 60.45; H, 4.06; N, 10.57. Found: C, $60.71 ; \mathrm{H}, 3.76 ; \mathrm{N}, 10.65 ; \mathrm{mp}=240-247^{\circ} \mathrm{C}$ (decomposition); $R_{f}$ value in system $1=0.78$ and in system $2=0.39$. 
e)1-Cyclopropyl-6-fluoro-8-nitro-4-oxo-7-(4-chloro-phenylamino)-1,4-dihydro-quinoline-3-carboxylic acid (9e)

A stirred mixture of 4-chloroaniline (1.15 g, $9 \mathrm{mmol}$ ), 7-chloro-1-cyclopropyl-6-fluoro-8-nitro-4oxo-1,4-dihydroquinoline-3-carboxylic acid (3, $1.0 \mathrm{~g}, 3 \mathrm{mmol})$ and sodium hydrogen carbonate (1.5 g, $18 \mathrm{mmol})$ in $50 \%$ aqueous ethanol $(140 \mathrm{~mL})$ was heated at $70-75{ }^{\circ} \mathrm{C}$ for $230-240 \mathrm{~h}$ under reflux conditions. Work-up of the resulting reaction mixture was carried out as described for 9a above, producing the title compound as pale brown solid. Crystallization of the crude mixture gave two spots on TLC; one was faint and the other was condensed. NMR analysis showed more than one compound but the peaks of 9e were distinct and could be recognized. First attempt: The 7-hydroxy product 10 was major but not the product. Second attempt: Minor with the 7-ethoxy side product 11. ${ }^{1} \mathrm{H}$-NMR (DMSO-d $\mathrm{d}_{6} / \mathrm{CO}\left(\mathrm{CD}_{3}\right)_{2}$ ), minor: $\delta 1.01$ (m, 4H, $\left.\mathrm{H}_{2}-2^{\prime} / \mathrm{H}_{2}-3^{\prime}\right), 3.87$ (m, 1H, H.1'), 7.05 (d, $J=8.7 \mathrm{~Hz}, 2 \mathrm{H}$, H-2"/H-6"), 7.31 (d, $\left.J=8.7 \mathrm{~Hz}, 2 \mathrm{H}, \mathrm{H}-3^{\prime \prime} / \mathrm{H}-5^{\prime \prime}\right), 8.22$ (d, $\left.{ }^{3} J_{\mathrm{H}-\mathrm{F}}=11.4 \mathrm{~Hz}, 1 \mathrm{H}, \mathrm{H}-5\right), 8.84$ (s, 1H, H-2), 9.10 (br s, 1H, NH-Ar), 14.25 (br s, 1H, COOH); IR (KBr): $v$ 3376, 3093, 2918, 2849, 2362, 1621, $1585,1542,1472,1366,1285,1175,1090,1015 \mathrm{~cm}^{-1}$; mp = 175-180 ${ }^{\circ} \mathrm{C}$ (decomposition); $R_{f}$ value in system $1=0.81$ and in system $2=0.875$.

\section{f) 1-Cyclopropyl-6-fluoro-8-nitro-4-oxo-7-phenylamino-1,4-dihydro-quinoline-3-carboxylic acid (9f).}

A stirred mixture of aniline (0.84 g, $0.82 \mathrm{~mL}, 9 \mathrm{mmol})$, 7-chloro-1-cyclopropyl-6-fluoro-8-nitro-4oxo-1,4-dihydroquinoline-3-carboxylic acid (3,1.0 g, $3 \mathrm{mmol}$ ) and sodium hydrogen carbonate (1.5 g, $18 \mathrm{mmol})$ in $50 \%$ aqueous ethanol $(140 \mathrm{~mL})$ was heated at $40-45{ }^{\circ} \mathrm{C}$ for $132-144 \mathrm{~h}$ under reflux conditions. Work-up of the resulting reaction mixture was carried out as indicated for $\mathbf{7 b}$ to give a dark yellow powder. NMR analysis of the product showed that the 7-ethoxy compound $\mathbf{1 1}$ was the major product, but the presence of the title compound was detected. Chromatography failed to separate the product in pure form. Yield $\approx 0.43 \mathrm{~g}(44 \%)$; ${ }^{1} \mathrm{H}-\mathrm{NMR}$ (DMSO-d $)$, minor: $\delta 0.92,1.10\left(2 \mathrm{~m}, 4 \mathrm{H}, \mathrm{H}_{2}-\right.$ 2'/ $\mathrm{H}_{2}-3^{\prime}$ ), 3.65 (m, $\left.1 \mathrm{H}, \mathrm{H}-1^{\prime}\right)$, 6.95-7.27 (m, 5H, Ar-H), 7.85 (br s, $1 \mathrm{H}, \mathrm{NH}$ ), 8.33 (d, ${ }^{3} J_{\mathrm{H}-\mathrm{F}}=13.0 \mathrm{~Hz}$, $1 \mathrm{H}, \mathrm{H}-5), 8.62$ (s, 1H, H-2), 14.30 (s, $1 \mathrm{H}, \mathrm{CO}_{2} \mathrm{H}$ ); IR (KBr): v 3430, 3083, 2924, 2851, 1702, 1604, 1539, 1464, 1390, 1340, 1265, 1191, 1096, $1039 \mathrm{~cm}^{-1}$; Anal. Calcd. for $\mathrm{C}_{19} \mathrm{H}_{14} \mathrm{FN}_{3} \mathrm{O}_{5}$ (383.33): C, 59.53; H, 3.68; N, 10.96. Found: C, 59.40; H, 3.61; N, 10.90; $\mathrm{mp}=250-256{ }^{\circ} \mathrm{C}$ (decomposition); $R_{f}$ value in system $1=0.70$ and in system $2=0.85$;

\section{g) 7-Amino-1-cyclopropyl-6-fluoro-8-nitro-4-oxo-1,4-dihydroquinoline-3-carboxylic acid (9g).}

Method A: A mixture of 7-chloro-1-cyclopropyl-6-fluoro-8-nitro-4-oxo-1,4-dihydroquinoline-3carboxylic acid (3, $1.3 \mathrm{~g}, 4 \mathrm{mmol})$, ammonium hydroxide $(28 \%, 8 \mathrm{~mL})$ and pyridine $(8 \mathrm{~mL})$ was stirred for 17 hours in a round bottom flask at R.T. Excess ammonia (4 mmol) was added every 2-3 h until the starting material spot disappeared on TLC. The reaction mixture was evaporated to dryness to give an orange residue. The orange residue was triturated with water-acetic acid (10:1, $44 \mathrm{~mL})$, filtered, washed with water, and then re-crystallized to give 7-amino-1-cyclopropyl-6-flouro-8-nitro1,4-dihydro-4-oxo-3-quinoline carboxylic acid $\mathbf{9 g}$ as orange crystals (Scheme 2). Yield $\approx 0.92 \mathrm{~g}$ (75 \%); ${ }^{1} \mathrm{H}-\mathrm{NMR}\left(\mathrm{CDCl}_{3}\right): \delta 1.17,1.29\left(2 \mathrm{~m}, 4 \mathrm{H}, \mathrm{H}_{2}-2^{\prime} / \mathrm{H}_{2}-3^{\prime}\right), 3.78\left(\mathrm{~m}, 1 \mathrm{H}, \mathrm{H}-1^{\prime}\right), 6.7$ (br s, $2 \mathrm{H}, \mathrm{NH}_{2}$, 
exchangeable), $8.47\left(\mathrm{~d},{ }^{3} \mathrm{~J}_{\mathrm{H}-\mathrm{F}}=7.8 \mathrm{~Hz}, 1 \mathrm{H}, \mathrm{H}-5\right), 8.94(\mathrm{~s}, 1 \mathrm{H}, \mathrm{H}-2), 13.71\left(\mathrm{~s}, 1 \mathrm{H}, \mathrm{CO}_{2} \mathrm{H}\right) ;{ }^{13} \mathrm{C}-\mathrm{NMR}$ (CDCl3): $\delta 11.3$ (C-2'/C-3'), 38.8(C-1'), 109.9 (C-3), 115.0 (d, $\left.{ }^{2} J_{\mathrm{C}-\mathrm{F}}=23 \mathrm{~Hz}, \mathrm{C}-5\right), 127.6$ (d, ${ }^{3} J_{\mathrm{C}-\mathrm{F}}=6.7$ Hz, C-4a), 131.0 (C-8), 134.3 (d, $\left.{ }^{2} J_{\mathrm{C}-\mathrm{F}}=23.2 \mathrm{~Hz}, \mathrm{C}-7\right), 140.0$ (C-8a), 151.8 (C-2), 155.1 (d, ${ }^{1} J_{\mathrm{C}-\mathrm{F}}=255$ $\mathrm{Hz}, \mathrm{C}-6), 164.7\left(\mathrm{CO}_{2} \mathrm{H}\right), 175.8\left(\mathrm{~d},{ }^{4} J_{\mathrm{C}-\mathrm{F}}=1.8 \mathrm{~Hz}, \mathrm{C}-4\right)$; IR $(\mathrm{KBr}): v$ 3435, 3076, 2923, 1718, 1604, 1539, 1436, 1385, 1330, 1261, 1193, 1125, $1051 \mathrm{~cm}^{-1}$; Anal. Calcd. for $\mathrm{C}_{13} \mathrm{H}_{10} \mathrm{FN}_{3} \mathrm{O}_{5}$ (307.23): C, 50.82; H, 3.28; N, 13.68. Found: C, 50.76; H, 3.33; N, 13.49; $\mathrm{mp}=264-267{ }^{\circ} \mathrm{C}$ (decomposition); $R_{f}$ value in system $1=0.725$ and in system $2=0.875$.

Method B: This compound was also prepared by acid hydrolysis of ethyl 7-amino-1-cyclopropyl-6flouro-8-nitro-4-oxo-1,4-dihydroquinoline-3-carboxylate [15]. ${ }^{1} \mathrm{H}-\mathrm{NMR}$ (DMSO- $\mathrm{d}_{6}$ ): $\delta$ 1.06, 1.18 (2m, $4 \mathrm{H}, \mathrm{H}_{2}-2^{\prime} / \mathrm{H}_{2}-3^{\prime}$ ), 3.74 (m, $1 \mathrm{H}, \mathrm{H}-1^{\prime}$ ), 6.8 (br s, $2 \mathrm{H}, \mathrm{NH}_{2}$, exchangeable), 8.51 (d, ${ }^{3} J_{H-F}=8.4 \mathrm{~Hz}, 1 \mathrm{H}, \mathrm{H}-$ 5), 8.82 (s, $1 \mathrm{H}, \mathrm{H}-2), 13.81\left(\mathrm{~s}, 1 \mathrm{H}, \mathrm{CO}_{2} \mathrm{H}\right)$.

Side products:

a) 1-Cyclopropyl-6-fluoro-7-hydroxy-8-nitro-4-oxo-1,4-dihydro-quinoline-3-carboxylic acid (10).

A stirred mixture of 2-aminonicotinic acid (1.25 g, $9 \mathrm{mmol})$, 7-chloro-1-cyclopropyl-6-fluoro-8nitro-4-oxo-1,4-dihydroquinoline-3-carboxylic acid (3,1.0 g, $3 \mathrm{mmol})$ and sodium hydrogen carbonate $(1.5 \mathrm{~g}, 18 \mathrm{mmol})$ in $50 \%$ aqueous ethanol $(140 \mathrm{~mL})$ was heated at 70-75 $₫$ under reflux conditions. TLC of the resulted solution at different intervals showed that the reaction proceeded very slowly, producing two faint yellow spots. After 5 weeks, more $\mathrm{NaHCO}_{3}(0.25 \mathrm{~g}, 3 \mathrm{mmol})$ and 2-aminonicotinic acid ( $0.6 \mathrm{~g}, 4.5 \mathrm{mmol})$ were added and the reaction mixture was heated at 80 under reflux conditions for another 3 weeks. Extraction with $\mathrm{CHCl}_{3}$ was carried out three times and a fourth extraction was also carried out after decreasing $\mathrm{pH}$ to 7 using $3.5 \mathrm{~N} \mathrm{HCl}$. The chloroform extracts were collected and, the side product $\mathbf{1 1}$ was re-crystallized from chloroform and ethanol (3:1) as yellow crystals. The $\mathrm{pH}$ of the aqueous solution was decreased to about 2 and the resulting precipitate was collected by suction filtration, washed with water and dried. Recrystallization from ethanol (30 $\mathrm{mL})$ produced 10 as an off-white powder. Yield $\approx 0.75 \mathrm{~g}$ (75 \%); ${ }^{1} \mathrm{H}-\mathrm{NMR}$ (DMSO- $\mathrm{d}_{6}$ ): $\delta$ 0.97, 1.07 (2m, $4 \mathrm{H}, \mathrm{H}_{2}-2^{\prime} / \mathrm{H}_{2}-3^{\prime}$ ), 3.66 (m, $1 \mathrm{H}, \mathrm{H}-1^{\prime}$ ), 4.95 (br s, $1 \mathrm{H}, \mathrm{OH}$, disappeared in acetone), 8.10 (d, ${ }^{3} J_{\mathrm{H}-\mathrm{F}}=10.57$ $\mathrm{Hz}, 1 \mathrm{H}, \mathrm{H}-5), 8.66$ (s, 1H, H-2), 14.39 (br s, 1H, $\mathrm{CO}_{2} \mathrm{H}$ in acetone only, did not appear in DMSO); ${ }^{13} \mathrm{C}-\mathrm{NMR}$ (DMSO-d ${ }_{6}$ ): $\delta$ 10.8, 10.9 (C-2'/C-3'), 39.59 (C-1'), 108.38 (C-3), 113.0 (d, ${ }^{2} J_{\mathrm{C}-\mathrm{F}}=19.4 \mathrm{~Hz}$, C-5), 116.99 (d, $\left.{ }^{3} J_{\mathrm{C}-\mathrm{F}}=5.2 \mathrm{~Hz}, \mathrm{C}-4 \mathrm{a}\right), 132.36$ (C-8), 133.05 (C-8a), 148.75 (d, ${ }^{2} J_{\mathrm{C}-\mathrm{F}}=20.8 \mathrm{~Hz}, \mathrm{C}-7$ ), $150.92\left(\mathrm{~d},{ }^{1} J_{\mathrm{C}-\mathrm{F}}=247 \mathrm{~Hz}, \mathrm{C}-6\right), 151.58(\mathrm{C}-2), 165.57\left(\mathrm{CO}_{2} \mathrm{H}\right), 175.92\left(\mathrm{~d},{ }^{4} J_{\mathrm{C}-\mathrm{F}}=2.7 \mathrm{~Hz}, \mathrm{C}-4\right)$; IR (KBr): $v$ 3431, 3076, 2362, 1717, 1619, 1538, 1470, 1339, 1292, 1253, 1220, 1113, $1032 \mathrm{~cm}^{-1}$; Anal. Calcd. for $\mathrm{C}_{13} \mathrm{H}_{9} \mathrm{FN}_{2} \mathrm{O}_{6}$ (308.22): C, 50.66; H, 2.94; N, 9.09. Found: C, 49.98; H, 2.93; N, 9.01; mp = $240-249^{\circ} \mathrm{C}$ (decomposition); $R_{f}$ value in system $1=0.413$ and in system $2=0.15$.

\section{b) 1-Cyclopropyl-7-ethoxy-6-fluoro-8-nitro-4-oxo-1,4-dihydro-quinoline-3-carboxylic acid (11)}

The same reaction mentioned above for production of $\mathbf{1 0}$, also produced as an additional side product ethoxy cipro acid (1-cyclopropyl-7-ethoxy-6-fluoro-8-nitro-4-oxo-1,4-dihydro-quinoline-3- 
carboxylic acid, 11). Work up and re-crystallization were as mentioned above. This product was isolated from chloroform extracts at $\mathrm{pH}$ above 7 . Yield $\approx 0.25 \mathrm{~g}(25 \%) ;{ }^{1} \mathrm{H}-\mathrm{NMR}$ (DMSO- $\mathrm{d}_{6}$ ): $\delta 1.02$, 1.15 (2m, 4H, Hz-2'/ $\mathrm{H}_{2}-3^{\prime}$ ), 1.28 (t, $J=7.0 \mathrm{~Hz}, 3 \mathrm{H}, \mathrm{CH}_{3}$ ), 3.69 (m, 1H, H-1'), 4.46 (q, $J=6.95 \mathrm{~Hz}, 2 \mathrm{H}$, $\left.\mathrm{OCH}_{2} \mathrm{CH}_{3}\right), 8.31\left(\mathrm{~d},{ }^{3} J_{\mathrm{H}-\mathrm{F}}=11.47 \mathrm{~Hz}, 1 \mathrm{H}, \mathrm{H}-5\right), 8.78$ (s, $\left.1 \mathrm{H}, \mathrm{H}-2\right), 14.05$ (br s, $\left.1 \mathrm{H}, \mathrm{CO}_{2} \mathrm{H}\right) ;{ }^{13} \mathrm{C}-\mathrm{NMR}$ $\left(\mathrm{CDCl}_{3}\right): \delta 10.95\left(\mathrm{C}-2^{\prime} / \mathrm{C}-3^{\prime}\right), 15.66\left(\mathrm{CH}_{3}\right), 39.45\left(\mathrm{C}-1^{\prime}\right), 72.96$ (d, $\left.J=7.5 \mathrm{~Hz}, \mathrm{OCH}_{2} \mathrm{CH}_{3}\right), 108.89(\mathrm{C}-$ 3), $115.66\left(\mathrm{~d},{ }^{2} J_{\mathrm{C}-\mathrm{F}}=20.8 \mathrm{~Hz}, \mathrm{C}-5\right), 122.74$ (d, $\left.{ }^{3} J_{\mathrm{C}-\mathrm{F}}=6.53 \mathrm{~Hz}, \mathrm{C}-4 \mathrm{a}\right), 131.61$ (C-8), 136.42 (C-8a), $145.78\left(\mathrm{~d},{ }^{2} J_{\mathrm{C}-\mathrm{F}}=16.68 \mathrm{~Hz}, \mathrm{C}-7\right), 152.11\left(\mathrm{~d},{ }^{1} J_{\mathrm{C}-\mathrm{F}}=247.13 \mathrm{~Hz}, \mathrm{C}-6\right), 152.72(\mathrm{C}-2), 165.06\left(\mathrm{CO}_{2} \mathrm{H}\right)$, 175.89 (C-4); IR (KBr): $v$ 3440, 3054, 2921, 2852, 2363, 1722, 1614, 1544, 1456, 1363, 1286, 1102, $1014 \mathrm{~cm}^{-1}$; Anal. Calcd. for $\mathrm{C}_{15} \mathrm{H}_{13} \mathrm{FN}_{2} \mathrm{O}_{6}$ (336.27): C, 53.58; H, 3.90; N, 8.33. Found: C, 53.65; $\mathrm{H}$, $4.31 ; \mathrm{N}, 7.97 ; \mathrm{mp}=203-206{ }^{\circ} \mathrm{C}$ (decomposition); $R_{f}$ value in system $1=0.825$ and in system $2=$ 0.925 .

\section{Antibacterial screening:}

All the chemical compounds were tested for antibacterial activity against human pathogens Gramnegative (E. coli. ATCC 8739) and Gram-positive bacteria (Staphylococcus aureus ATCC 6538). The minimal inhibitory concentration (MICs) of the chemical compounds assays were carried out as described by Foroumadi et al. [2,3], with minor modification. Ciprofloxacin was used as reference antibacterial agent.

\section{a) Determination of inhibition zones (agar diffusion method):}

A drop of bacteria was added to sterile nutrient agar $(20 \mathrm{~mL})$, poured into a plate $(9 \mathrm{~cm}$ in diameter) and allowed to solidify to obtain the seeded agar. The final concentration of the microorganisms in the agar plate was $1-4 \times 10^{5} \mathrm{cfu}^{-1} \mathrm{~mL}^{-1}$ (checked by viable counting in normal saline). Aliquots of $25 \mu \mathrm{L}$ of the freshly prepared saturated solutions of the synthesized compounds (Table 1) were poured in wells ( $7 \mathrm{~mm}$ in diameter). Plates were then incubated at $37{ }^{\circ} \mathrm{C}$ for $24 \mathrm{~h}$. The zones of inhibition were determined as the diameter of the zone of inhibition around the well solution for each compound at its saturated concentration (Table 1). Solvent (DMSO) was included in every experiment of determining zones of inhibition as a control to ensure that it has no effect on the bacterial growth. Each experiment was done in duplicate.

\section{b) Determination of minimum inhibitory concentration, MIC, (serial dilution method):}

Stock solutions were prepared by dissolving each pure compound (5 mg) in $5 \mathrm{~mL}$ of DMSO then 1 $\mathrm{mL}$ of the compound stock solution was added to nutrient broth $(4 \mathrm{~mL})$. Progressive twofold serial dilutions of the stock solutions were made in nutrient broth starting from $100 \mu \mathrm{g} / \mathrm{mL}$ concentrations in the first test tubes and ending with a concentration of $3.05 \times 10^{-3} \mu \mathrm{g} / \mathrm{mL}$.

The standardization of bacterial test suspension was carried out according to the McFarland standard method as described by the National Committee for Clinical Laboratories Standard (NCCLS) (1993). One drop of bacterial suspension was added to the test tubes containing graded concentrations 
of test compounds to yield final consent-ration of $1-4 \times 10^{6} \mathrm{cfu} \cdot \mathrm{mL}^{-1}$. Test tubes were incubated at 37 ${ }^{\circ} \mathrm{C}$ for $24 \mathrm{~h}$ and were checked for turbidity. Each experiment was done in duplicate.

Control tests for each experiment were performed. Positive growth control was performed by adding one drop of each micro-organism suspensions to a test tube of the culture medium without the test compound. Negative growth control was also performed using un-inoculated tube of medium without the test compound. Both were incubated for $24 \mathrm{~h}$ at $37^{\circ} \mathrm{C}$ for both types of bacteria following reported procedures.

Positive and negative controls were performed with DMSO at the same dilutions as in the experiment to ensure that it is incapable of inhibiting the growth of bacteria. Test tubes were incubated at $37{ }^{\circ} \mathrm{C}$ for $24 \mathrm{~h}$ and found to have no effect on microbial growth at tested concentrations. This procedure was modified from reported literature $[2,3,16]$.

\section{Cytotoxicity on cancerous epithelial cells}

MCF-7 cells were trypsinizd, seeded in 96 well plates and incubated for 24 hours. The tested derivatives were diluted with RPMI 1640 cell culture media, added to the cells, and incubated at three concentrations of 10,30 , and $100 \mu \mathrm{g} / \mathrm{mL}$. The cells were incubated with the compounds for 48 hours and sulphrodamine B assay was run afterwards. All tests were done in triplicates and repeated twice using two different passages.

\section{Acknowledgments}

Authors wish to thank Deanship of Academic Research, Deanship of Post Graduate Studies and the Faculty of Pharmacy, University of Jordan, Amman, Jordan for providing necessary facilities and funds for conducting this research. Authors wish to thank also librarians for providing the Scifinder services and e-Library facilities.

\section{References and Notes}

1. (a) Wise, R.; Andrews, J. M.; Edwards, L. J. In vitro activity of Bay 09867, a new quinoline derivative, compared with those of other antimicrobial agents. Antimicrob. Agents Chemother. 1983, 23, 559-564; (b) Felmingham, D.; O'Hare, M. D.; Robbins, M. J.; Wall, R. A.; Williams, A. H.; Cremer, A. W.; Ridgeway, G. L.; Gruneberg, R. N. Comparative in vitro studies with 4quinolone antimicrobials. Drugs Exp. Clin. Res. 1985, 11, 317-329; (c) Maurer, F.; Grohe, K. 2,4Dichloro-5-fluorobenzoic acid. Ger. Offen. 3,435,392, 1986; [Chem. Abstr. 1986, 105, 97158e]; (d) Petersen, U.; Bartel, S.; Bremm, K. D.; Himmler, T.; Krebs, A.; Schenke, T. The synthesis and biological properties of 6-fluoroquinolonecarboxylic acids. Bull. Soc. Chim. Belg. 1996, 105, 683699.

2. Foroumadi, A.; Mansouri, S.; Kiani, Z.; Rahmani, A. Synthesis and in vitro antibacterial evaluation of N-[5-(5-nitro-2-thienyl)-1,3,4-thiadiazole-2-yl] piperazinyl quinolones. Eur. J. Med. Chem. 2003, 38, 851-854. 
3. Foroumadi, A.; Soltani, F.; Moshafi, H. M.; Askari, R. A. Synthesis and in vitro antibacterial activity of some N-(5-aryl-1,3,4-thiadiazole-2-yl)piperazinyl quinolone derivatives. Farmaco 2003, 58, 1023-1028.

4. Cianchetta, G.; Mannhold, R.; Cruciani, G.; Baroni, M.; Cecchetti, V. Chemometric studies on the bactericidal activity of quinolones via an extended VolSurf approach. J. Med. Chem. 2004, 47, 3193-3201.

5. Ziegler, C. B.; Curran, W. V.; Kuck, N. A.; Harris, S. M.; Lin, Y. I. Synthesis and antibacterial activity of some 7-substituted 1-ethyl-6-fluoro-1,4-dihydro-4-oxoquinoline-3-carboxylic acids: ethers, secondary amines and sulfides as C7 substituents. J. Heterocycl. Chem. 1989, 26, 11411145.

6. Silva, A. D.; Almeida, M. V.; Souza, M. V. N.; Couri, M. R. C. Biological activity and synthetic methodologies for the preparation of fluoroquinolones, a class of potent antibacterial agents. Curr. Med. Chem. 2003, 10, 21-39.

7. Sanchez, J. P.; Domagala, M.; Hagen, S. E.; Heifetz, C. L.; Hutt, M. P.; Nichols, J. P.; Trehan, A. K. Quinolone antibacterial agents. Synthesis and structure-activity relationships of 8-substituted quinoline-3-carboxylic acids and 1,8-naphthyridine-3-carboxylic acids. J. Med. Chem. 1988, 31, 983-991.

8. (a) Qaisi, A. M. M.; Al-Hiari, Y. M. A.; Zahra, J. A. Y.; El-Abadelah, M. M. M. Quinoline and pyridoquinoxaline derivatives as antibacterial agents. Eur. Pat. Appl. 2006, EP 2006-252509 20060512, [Chem. Abstr. 2006, 120, 9765]; (b) Shoaa, A. R. Compounds with antibacterial and antiparasitic properties. PCT Internat. Appl. WO 2001-036408 A1, 2001, [Chem. Abstr. 2001, 135, 5534]; (c) Khalil, O. M.; Roshdy, S. M. A.; Shaaban, M. A.; Hasanein, M. K. New 7substituted fluoroquinolones. Bull. Fac. Pharm. 2002, 40, 89-96.

9. (a) Grohe, K.; Heitzer, H. Cycloaracylation of enamines. I. Synthesis of 4-quinolone-3-carboxylic acids. Liebigs. Ann. Chem. 1987, 1, 29-37; (b) Petersen, U.; Grohe, K.; Schenke, T.; Hagemann, H.; Zeiler, H. J.; Metzger, K. G. Preparation of 7-(azabicycloalkyl)-3-quinoline-carboxylates and 3-naphthyridinecarboxylates as bactericides and feed additives. Ger. Offen. 3601567, 1987; [Chem. Abstr., 1987, 107, 236747]; (c) Pulla, R. M.; Venkaiah, C. N. An improved process for the preparation of quinolone derivatives, e.g. Ciprofloxacin. PCT Int. Appl. WO 085 692. 2001; [Chem. Abstr. 2001, 135, 371649].

10. Domagala, J. M.; Peterson, P. New 7-Substituted Quinolone Antibacterial Agents.II. The Synthesis of 1-Ethyl-1,4-dihydro-4-oxo-7-(pyrazolyl, isoxazolyl, and pyrimidinyl)-1,8naphthyridine and quinolone-3-carboxylic Acids. J. Heterocycl. Chem. 1989, 26, 1147-58.

11. Renau, T. E.; Sanchez, J. P.; Gage, J. W.; Dever, J. A.; Shapiro, M. A.; Grackeck, S. J.; Domagala, J. M. Structure-Activity Relationships of the Quinolone Antibacterials against Mycobacteria: Effect of Structural Changes at N-1 and C-7. J. Med. Chem. 1996, 39, 729-735.

12. Takemura, M.; Hayakawa, I. Recent advances in the field of quinolones. Farmaco 2001, 56, 3740.

13. Koga, H.; Itoh, A.; Murayama, S.; Suzue, S.; Irikura, T. Structure-Activity Relationships of Antibacterial 6,7- and 7,8-Disubstituted 1-Alkyl-1,4-dihydro-4-oxoquinoline-3-carboxylic acid. Med. Chem. 1980, 23, 1358-63. 
14. (a) Fisher, L. M.; Lawrence, J. M.; Josty, I. C.; Hopewell, R.; Margerrison, E. E.; Cullen, M. E. Ciprofloxacin and the fluoroquinolones. New concepts on the mechanism of action and resistance. Am. J. Med. 1989, 87 (5A): 2S-8S; (b) Chen, F.-J.; Lo, H.-J. Molecular mechanisms of fluoroquinolone resistance. J. Micro. Immun. Infec. (Wei mian yu gan ran za zhi ) 2003, 36, 1-9.

15. Al-Hiari, Y. M.; Khanfar, M. A.; Qaisi, A. M.; Abu-Shuheil, M. Y.; El-Abadelah, M. M.; Boese, R. Heterocycles $[h]$ Fused onto 4-Oxoquinolines. Part I. Formal Synthesis and Properties of 6Oxo-6,9-dihydro[1,2,5] oxadiazolo[3,4- $h$ ]quinoline-7-carboxylic acid N-oxide. Heterocycles 2006, 68, 1163-1172.

16. Sarma, M. R.; Kumar, N. V.; Prasad, A. S. R.; Oaraiah, E. S.; Prabhakar, C.; Reddy, G. O.; Kumar, M. S.; Sadhukhan, A. K.; Venkateswarlu, A.; Reddy, K. A. Synthesis and biological activity of novel antibacterial quinolones. Ind. J. Chem. 2001, 40B, 331-335.

Sample Availability: Contact the authors.

(c) 2007 by MDPI (http://www.mdpi.org). Reproduction is permitted for noncommercial purposes. 